\title{
Critical Reading and Writing: A Literary Project for Non-English Majors with Thinking Tools
}

\author{
Ai Chun Yen \\ Dong Hwa University
}

\begin{abstract}
This paper discusses how EFL non-English majors'critical reading and writing awareness in English can be developed in a literature-based class for general education. This module was designed for non-English majors to read the classic literary texts with e-story mapping (hereafter called the "Literary Project" or the "Project") at Dong Hwa University, Taiwan. The Literary Project centered on how context shaped students' critical reading and writing skills and to further their knowledge management. The 4P model-plan-produce-publish-present-was introduced in the first class and framed in such a way as to contextualize reading analytically first and later writing academically. At the same time, it provides principles for the researcher to organize the rubrics to assess students' performance for data analysis. Strategies and productions addressed in this paper were research-based and practical in application. The analysis of participants 'progress in collaborative reading and writing through the use of e-story mapping shows that the $4 P$ model helps them to concentrate on critical reading and writing components in a different, but complementary manner depending on whether they are engaged in the e-story mapping.
\end{abstract}

Keywords: critical reading, critical writing, e-story mapping, learning management system, knowledge management

\section{Introduction}

\subsection{Research Background}

Critical literacy is the fundamental value that university students should acquire in order to become socialized in their disciplinary communities at the university and after graduation, of which reading and writing in English are the most important skills for non-native speakers. The current paper presents how non-English majors' critical reading and writing awareness in English was developed in an Introduction to Western Literature class for general education in e-story mapping through a learning management system (hereafter called "e-story map- ping" and "LMS") at Dong Hwa University, Taiwan. The Literary Project encourages the peer-to-peer networking and group learning that are central to a constructivist learning approach, which has as its mainstay e-story maps. Despite extensive research about L2 reading and writing skills, less is known about e-story mapping in critical reading and writing in literary texts at the university level.

The e-story map in the current study is a strategy to help students learn the elements of a literary text. Tasked with identifying the characters, plot, setting, problem, and solution, students read carefully to learn the details and 
then create a map to increase their comprehension by organizing and sequencing the main story events. The e-story map also enables students to build their interpretative abilities by allowing them to visualize the characters, events, and settings. E-story maps can be used as frameworks for storytelling or retelling, as well as outlines for story writing. This procedure enables students to relate story events and perceive structure in literary selections. This is not a linear learning style, but an organic one. By sharing personal interpretations of stories through illustrations in the university LMS, students increase their understanding and appreciation of literary selections.

To help the participants create their e-story maps, organize their knowledge in literature, and manage the knowledge gained after reading the texts, the 4P model, plan-produce-publish-present, was introduced in the first class. By framing the 4P model in such a way as to contextualize reading and writing, students' e-story maps were expected to be comparatively more comprehensible and academic. In order to assess students' critical reading and writing skills and remove the teacher's subjectivity and evaluator bias, the e-story mapping rubrics have been designed based on the 4P model. The 4P model of the current study set both a critical reading and writing inventory and the rubrics with which to observe and assess students' thinking process; it has been tested and revised on pilot groups of nonEnglish majors from two other classes a year before the current study.

\subsection{Research Questions}

The participants $(\mathrm{N}=40)$ were asked to read and think-aloud a literary text under one of the glosses of the 4P model. Though little is known of the value of collaborative reading and writing while using e-story mapping skills, this study aimed to investigate whether any of the conditions promoted observation and whether this observation led to better critical reading and writing. The study also aimed to understand the benefits students derive from working with the model while making use of thinking tools. Therefore, this study aimed to answer the following research questions:

1. Did the 4P model result in better critical reading (plan and produce)?

2. Did the $4 \mathrm{P}$ model result in better organization for critical writing (plan, produce, publish, and present)?

3. Did students become more involved in their e-story mapping when the 4P model worked as a guideline for critical reading and writing?

4. Did the 4P model help students to progress in their critical reading and writing?

\section{Literature Review}

Visual learning is a method that engages learners with concepts and information. It helps people associate concepts and information with images and represents them graphically, which aids students in constructing meaning (Bellanca, 1990; Jonassen, 1996; Tarquin \& Walker, 1997; Thornburg, 1998). Allen (2003) defined instructional interactivity as interaction that actively stimulates the learner's mind to do those things to improve ability and readiness to perform effectively. A story map is a visual interpretation of the settings or the sequence of major events and characters' actions in a text. Traditionally, some of the story maps are derived from plot structure or loosely adapted from story grammar. This helps serve as a means for investigating the characters of the story schema and develop a hypothesized mental structure for testing predictions about story processing (Spivey, 1989), which enables students to relate story events and perceive structure in literary selections (Stein \& Glenn, 1979).

However, because story maps are visual and depict associations oriented with a fo- 
cus on keywords in the literary texts, story map notes are much easier to memorize than linear notes. Story maps organize notes and ideas in such a way as to build up students' critical thinking and reasoning skills (in writing). Some researchers have shown interest in using story maps to increase reading comprehension (Baumann \& Bergeron, 1993; Davis \& McPherson, 1989; Duke \& Pearson, 2002; Katayama \& Robinson, 2000; Pearson, 1985; Stahl, 2004) and even to solve reading and writing difficulties (Berkeley, Scruggs, \& Mastropieri, 2010; Edmonds et al., 2009; Idolis, 1987; Zipprich, 1995). Story maps can be used as frameworks for surface reading, storytelling or retelling, critical reading, outlining as a prelude to story writing, and critical writing. The value of collaborative story mapping as a means to develop students' publication and presentation skills is also supported from a sociocultural perspective.

Learning is a process of acquiring sufficient cognitive and metacognitive awareness. Metacognition has been applied to educational studies for years. The basic theory is that when people do something, they are aware of not only what they are doing (object-level), but also how they are doing it (meta-level), although this awareness will not be recognized consciously (Dunlosky \& Metcalfe, 2009). Storch (2005) noted that in a collaborative situation, writers are impelled to make decisions about the language used to express their ideas, and thus, to formulate a structure through which to express those ideas as they produce a text together. To achieve their common goals, students must engage with each other. Therefore, the "knowledge," according to Franklin (1996, as cited in Wells, 2000), is what the students produce in black and white and "created and re-created in the discourse between people doing things together" (p. 71). By sharing interpretations of stories through illustrations, students increase their under- standing and unconsciously exchange their appreciation of selections.

In collaborative tasks, individual and shared processes and outcomes are often of interest to the teacher and researcher. Moore's typology (1989) includes learner-content, learnerinstructor, and learner-learner interactivity ( $p$. 2-4). Wells (2000) emphasized that "the joint attempt to construct common understandings" (p. 74) is superior to individual understandings because in this learning context the teacher is no longer viewed as the only active agent (who simply deposits knowledge into students). As was articulated by Daniel and Marquis (1988), interaction should "in a restrictive manner... cover only those activities where the student is in two-way contact with another person (or persons)" (p. 339). They rightly pointed out that different forms of education have different pedagogical and social characteristics and that no single form possesses the "perfect" mix that meets all learner and institutional needs across all curricula and content.

Swain (2000) also stressed the weight of collaborative dialogue in that students" "jointly constructed performance outstrips their individual competences" (p. 111). Interactivity is shown to be the single factor that binds all the elements together to build a conversational learning community. Markwood and Johnstone (1994) describe interaction as the "silent, critical, creative conversation within the learner's mind that is stimulated and supported by the learning environment" (p. 94). The most recent trend in collaborative learning is computer-supported collaborative learning (hereafter called "CSCL"), which concerns how learners learn together with others with the help of computers in and outside the classroom (Jonassen, 1996; Stahl, Koschmann, \& Suthers, 2006; Westera, 2010).

The learners negotiate meaning through computer-mediated communication, and the 
discourse is text-based and asynchronous, which helps learners think and modify what they will share and to what they will respond via computer-mediated devices. Resta and Laferriere's (2007) point out the learning benefits of CSCL for higher order thinking skills and productivity do coincide with Francescato et al.'s (2006) belief in CSCL's potential in helping learners promote their higher order cognitive processes, learn from one another, and create collective knowledge by sharing prior and newly gained knowledge. Because of this specific learning feature, CSCL helps learners' metacognition and self-awareness to grow more than in-class learning features. Therefore, students' learning behaviors with CSCL allow them to work with greater efficacy and effectiveness.

The research studies mentioned above are based on the underlying assumptions that individuals are active agents and are purposefully constructing knowledge within a meaningful context. Integrating CSCL with the learning

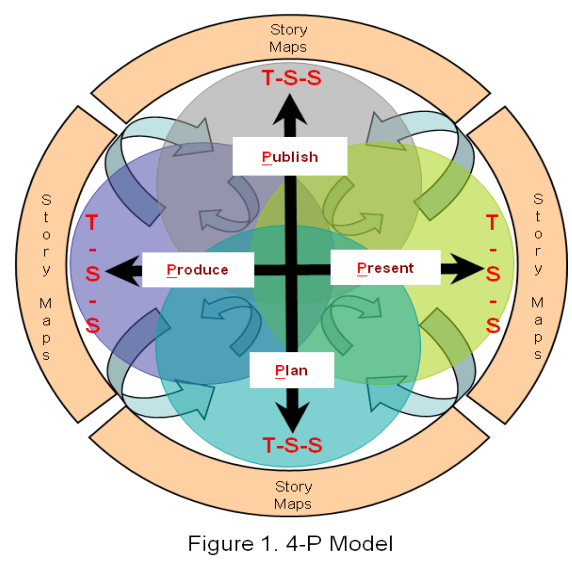

Figure 1. 4P Model

theory (1984, p. 141, see Figure 2), and learning achievement was developed cooperatively from collaborative work via the 4P model.

There was nevertheless a broad agreement that students understood the purpose of tool, e-story mapping, appears to be the emerging core of this study. As an initial attempt, the present researcher finalized a preliminary model after performing pilot studies designed to assess CSCL performance and a peer review tool for critical reading and writing at the university level. A continuing goal in this CSCL research is to develop and examine multiple methods of facilitating and supporting individual construction and co-construction of knowledge to shed light on the foundation for further analysis of group meaning making in CSCL.

\section{Research Method}

\subsection{Research Model and Research Process}

The class was divided into 10-20 person groups formed randomly per reading unit and was asked to organize their individual and group story maps by planning, producing, publishing, and presenting. The 4P model (see Figure 1), plan-produce-publish-present, was modified from Kolb's experiential learning

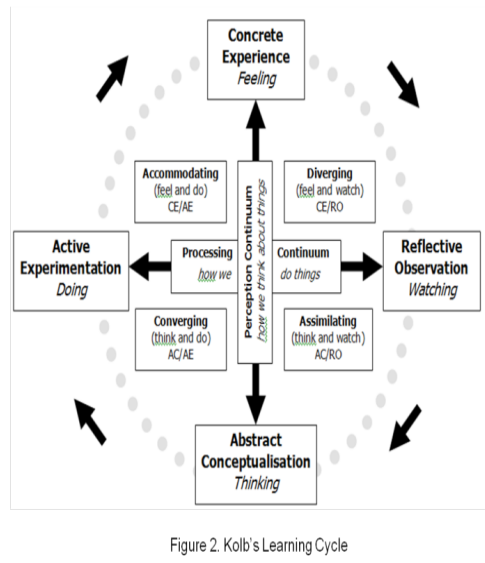

Figure 2. Kolb's Learning Cycle

the Project and the use of the university LMS (see Figure 3), explicitly accepted responsibility for their learning, took initiative in planning and executing learning activities, shared in setting the learning goals, regularly reviewed their maps via LMS (Moodle platform), and 

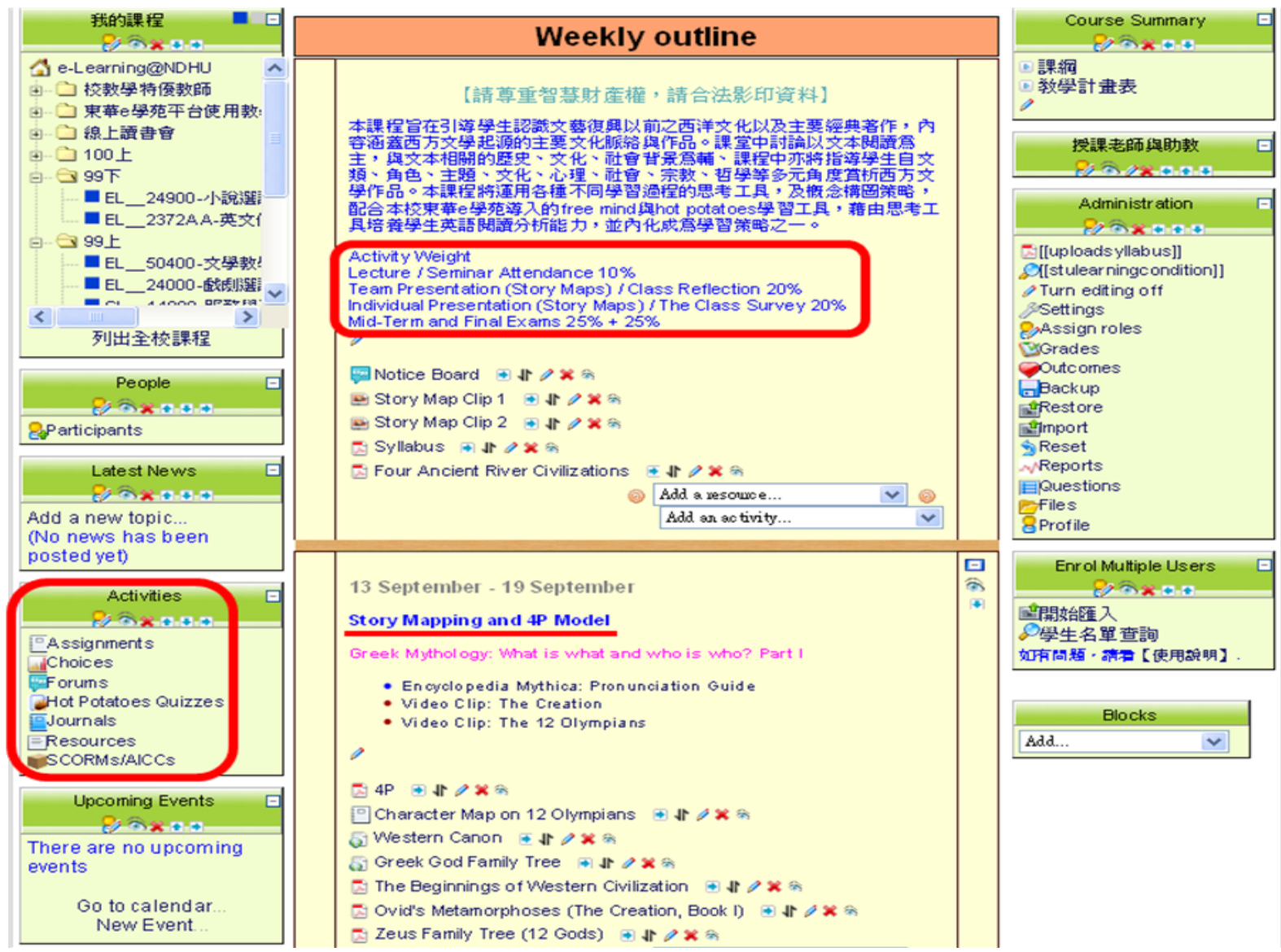

Figure 3. Course outline on University LMS

evaluated their research process and presentation style for their individual and group estory maps and for the final e-story map posters. Stages in the course design had not been sequenced, but occurred simultaneously. As Kolb (1984) suggested, when confronted with a new learning situation, students internally decide whether they wish to "do" or "watch" and at the same time whether to "think" or "feel." Therefore, even though the stages were mentioned in a certain order, the students did not necessarily follow this sequence. In fact, some stages overlapped. Students carried out a series of exercises designed to put them in touch with the reading and writing collages both in daily and academic life, and to approach the poster presentations for their e-story mapping in terms of their topic collages.

\subsection{Research Process}

Initially, the four codes (4Ps) were introduced and presented in order to scaffold the follow-up learning. Forty subjects participated in this 18-week research using the university LMS to show their production of e-story maps.

3.2.1. Stage 1: Plan. Students in the class needed to apply a style to draft their e-story maps, and thus, accommodate their critical reading. When creating a map draft, students needed to identify their own perspective or that of the group, and tried to summarize the point of their e-story mapping in keywords because this would help them stay focused on the main point. This draft helped them to answer three questions: 1) What did we already know from the literary text, 2) On what aspect did we need to focus more in the text, and 3 ) 
How did we finalize what we have planned in our group maps? Therefore, the first point the students needed to cover was their map perspective. If the e-story mapping centered on a complicated term, a definition was often a good place to start.

3.2.2. Stage 2: Produce. Students attempted to answer the $5 \mathrm{w}+1 \mathrm{~h}$ question specifically with regard to content. Concrete texts were studied, focused on both macro and micro structures. When students organized their map layout, they swapped ideas. At this stage, they used an audience- and purpose-oriented approach to reading, writing, and speaking in which texts and contexts and process and product were taken into account. Students could see what had been thought before and built on that using the maps, which corresponded with the natural way all learning processes proceed. That is, each learning step corresponded with the level arrived at through previous learning stages.

3.2.3. Stage 3: Publish. E-story mapping was used in this Project because there was a built-in learning tool in the university LMS. It was not a freestyle reading and writing class. To begin, students needed to determine whether or not there was in fact a standard to which they could refer as acceptable academic writing behavior in their mapping. So, the sample e-story maps were studied before students published their maps. Students were told that long text in the maps was unwelcome. The assignment zone was for student readers to visit their individual and group maps and respond to them.

3.2.4. Stage 4: Present. Students jointly determined their production topic and planned and produced a complete project or project segment online. Therefore, at this stage, they learned to present their e-story map posters for the group project. In practice, with the $4 \mathrm{P}$ model for estory mapping, it is the learner who learns and not the teacher who teaches. The teacher facilitates learning, and the quality of this interaction is largely based on the relationship between them, where trust and empathy make learning experiences more pervasive, and therefore, influence the learner's behavior.

\subsection{Research Instrument}

The challenging part of the current study was not the module design but the measurement of collaboration, or more specifically, the development of valid and reliable instruments for evaluating the effectiveness of these tools for enhancing individual and group learning processes and outcomes. The instrument was developed through several phases of two pilot studies in order to investigate and establish construct validity and reliability. The valid samples numbered 31 out of 40 sets and 33 out of 40 (feedback). The researcher classified and identified students' common critical reading and writing problems and divided them into five categories to formulate the e-story mapping rubric in the pilot studies. Based on suggestions from participants in the pilot studies, the rubrics to examine the $4 \mathrm{P}$ performance was redefined by clarifying terminology and adjusting the concepts to improve understanding and feasibility.

The rubrics were constructed and then reviewed by experts for content. The final estory mapping rubrics measurement for the $4 \mathrm{P}$ model was determined by the most parsimonious fit between the fit indices, reliability, and theoretical concerns. Some definitions of the criteria were adjusted based on pilot reliability scores and the conceptual fit of criteria to the current theoretical and practical model. When finalizing the rubrics, a scale from 5 to 1 (excellent, proficient, adequate, limited, and insufficient/blank) was set (see Table 1). The Cronbach's alpha for internal consistency of the rubrics was 0.863 . The e-story mapping rubrics provided guidelines for reading and writing critically and were further used as an assessment tool for communicating expecta- 
Table 1. E-story Mapping Rubrics

\begin{tabular}{|c|c|c|c|c|c|}
\hline & 5 (Excellent) & 4 (Proficient) & 3 (Adequate) & 2 (Limited) & $\begin{array}{c}1 \text { (Insufficient/ } \\
\text { Blank) }\end{array}$ \\
\hline Plan & $\begin{array}{l}\text { Draws insight- } \\
\text { ful key ideas } \\
\text { that captivate the } \\
\text { e-story mapping } \\
\text { for the "Plan" } \\
\text { task. }\end{array}$ & $\begin{array}{l}\text { Draws logical } \\
\text { key ideas that } \\
\text { engage e-story } \\
\text { mapping for the } \\
\text { "Plan" task. }\end{array}$ & $\begin{array}{l}\text { Draws predict- } \\
\text { able key ideas } \\
\text { with the e-story } \\
\text { mapping for the } \\
\text { "Plan" task. }\end{array}$ & $\begin{array}{l}\text { Draws little } \\
\text { related key ideas } \\
\text { for the "Plan" } \\
\text { task with mini- } \\
\text { mal e-story map- } \\
\text { ping appeal. }\end{array}$ & $\begin{array}{l}\text { Draws unrelated } \\
\text { key ideas for the } \\
\text { "Plan" task to } \\
\text { draw almost no } \\
\text { - e-story mapping } \\
\text { appeal. }\end{array}$ \\
\hline & $\begin{array}{l}\text { Shows signifi- } \\
\text { cant information } \\
\text { from a variety } \\
\text { of sources that } \\
\text { captivates the } \\
\text { e-story mapping } \\
\text { for the "Pro- } \\
\text { duce" task. }\end{array}$ & $\begin{array}{l}\text { Shows relevant } \\
\text { information } \\
\text { from a variety } \\
\text { of sources that } \\
\text { engages the e- } \\
\text { story mapping } \\
\text { for the "Pro- } \\
\text { duce" task. }\end{array}$ & $\begin{array}{l}\text { Shows applica- } \\
\text { ble information } \\
\text { from a variety } \\
\text { of sources for } \\
\text { the e-story } \\
\text { mapping for the } \\
\text { "Produce" task. }\end{array}$ & $\begin{array}{l}\text { Shows little in- } \\
\text { formation for the } \\
\text { "Produce" task } \\
\text { with minimal } \\
\text { e-story mapping } \\
\text { appeal. }\end{array}$ & $\begin{array}{l}\text { Shows vague } \\
\text { e information from } \\
\text { a few sources for } \\
\text { the "Produce" } \\
\text { task to draw } \\
\text { almost no e-story } \\
\text { mapping appeal. }\end{array}$ \\
\hline Publish & $\begin{array}{l}\text { Uses symbols, } \\
\text { terms and lan- } \\
\text { guage in an } \\
\text { effective man- } \\
\text { ner that capti- } \\
\text { vates the e-story } \\
\text { mapping for the } \\
\text { "Publish" task. }\end{array}$ & $\begin{array}{l}\text { Uses symbols, } \\
\text { terms or lan- } \\
\text { guage in a clear } \\
\text { manner that en- } \\
\text { gages the e-story } \\
\text { mapping for the } \\
\text { "Publish" task. }\end{array}$ & $\begin{array}{l}\text { Uses symbols, } \\
\text { terms or lan- } \\
\text { guage to discuss } \\
\text { some major } \\
\text { ideas with the } \\
\text { e-story mapping } \\
\text { for the "Publish" } \\
\text { task. }\end{array}$ & $\begin{array}{l}\text { Uses basic } \\
\text { symbols, terms } \\
\text { or language in } \\
\text { a struggling } \\
\text { manner for the } \\
\text { "Publish" task } \\
\text { 'with minimal } \\
\text { e-story mapping } \\
\text { appeal. }\end{array}$ & $\begin{array}{l}\text { Uses vague sym- } \\
\text { bols, terms or } \\
\text { language for the } \\
\text { "Publish" task to } \\
\text { draw almost no } \\
\text { e-story mapping } \\
\text { appeal. }\end{array}$ \\
\hline & $\begin{array}{l}\text { Consistently use } \\
\text { new language } \\
\text { and interprets } \\
\text { figurative lan- } \\
\text { guage that capti- } \\
\text { vates the e-story } \\
\text { mapping for the } \\
\text { "Present" task. }\end{array}$ & $\begin{array}{l}\text { Frequently use } \\
\text { new language } \\
\text { and interprets } \\
\text { figurative lan- } \\
\text { guage that en- } \\
\text { gages the e-story } \\
\text { mapping for the } \\
\text { "Present" task. }\end{array}$ & $\begin{array}{l}\text { Sometimes use } \\
\text { new language } \\
\text { and interprets } \\
\text { figurative lan- } \\
\text { guage with the } \\
\text { e-story mapping } \\
\text { for the "Present" } \\
\text { task. }\end{array}$ & $\begin{array}{l}\text { Seldom use new } \\
\text { language and } \\
\text { interprets figura- } \\
\text { tive language } \\
\text { for the "Present" } \\
\text { task with mini- } \\
\text { mal e-story map- } \\
\text { ping appeal. }\end{array}$ & $\begin{array}{l}\text { se new } \\
\text { e and } \\
\text { ts figura- } \\
\text { guage } \\
\text { 'Pres- } \\
\text { k to draw } \\
\text { no e-story } \\
\text { g appeal. }\end{array}$ \\
\hline \multicolumn{6}{|c|}{ Achievement in Critical Reading and Writing } \\
\hline $\begin{array}{l}\text { Critical } \\
\text { Read- } \\
\text { ing and } \\
\text { Writing }\end{array}$ & $\begin{array}{l}\text { Insightful e- } \\
\text { story mapping } \\
\text { that provides } \\
\text { strong reason- } \\
\text { ing for the } \\
\text { "4P" task. }\end{array}$ & $\begin{array}{l}\text { Thoughtful e- } \\
\text { story mapping } \\
\text { that provides } \\
\text { convincing } \\
\text { reasoning for } \\
\text { the "4P" task. }\end{array}$ & $\begin{array}{l}\text { Good e-story } \\
\text { mapping that } \\
\text { provides clear } \\
\text { reasoning for } \\
\text { the " } 4 \mathrm{P} \text { " task. }\end{array}$ & $\begin{array}{l}\text { Blurred e- } \\
\text { story mapping } \\
\text { that provides } \\
\text { unfocused or } \\
\text { little for the } \\
\text { "4P" task. }\end{array}$ & $\begin{array}{l}\text { Poor e-story } \\
\text { mapping that } \\
\text { provides no or } \\
\text { vague reason- } \\
\text { ing for the } \\
\text { "4P" task }\end{array}$ \\
\hline & & & & $-1.4=\mathrm{E} \quad$ Total & $/ 5=$ \\
\hline
\end{tabular}


tions of participants' critical reading and writing quality. Mainly, they helped students to judge and revise their e-story maps before they shared or uploaded their work.

\section{Research Results}

\subsection{Data Analysis}

The data were collected and analyzed qualitatively. E-story maps for the assignments, choices of best e-story maps, discussion forum postings, and e-story map presentations (SCORMs/AICCs) were collected for data analysis. Four dimensions (4Ps) from the model were employed to guide participants' choices of best e-story maps, discussion forum postings, and e-story map presentations and guide the teacher-researcher in analyzing the collected data.

\subsection{Research Outcome}

4.2.1. Research Question 1. The first research question explored the potential of the 4Ps to produce better academic reading (plan and produce). The 4Ps was shown to be effective after a 9-week experiment (see Table 2) and proved to help students improve their academic skills in English reading and writing after the experience came to an end (16 weeks total). Students paid attention to aspects of literary devices or styles in order to plan well-organized maps, especially when comparing maps they produced among peers. The plan-produce correlation went from 0.204 to 0.572 in 7 weeks, which means if students are well instructed and scaffolded they will perform better in planning and producing a map using this system. E-story map readers typically do not read a map from start to finish from left to right or from the top down. Much of what is presented in the maps is reference information that allows map readers to quickly locate the materials they seek. This is similar to research behavior; every researcher has his or her own reference collecting and analysis system. By recognizing students' map producing habits, the researcher found they also built up their knowledge management as a bonus when practicing the 4P model.

Table 2. Correlations of Plan-Produce Performance (Weeks 2 \& 9, 4P Model).

\begin{tabular}{|c|c|c|c|c|c|c|c|c|c|}
\hline & & \multicolumn{2}{|c|}{ Plan } & \multicolumn{2}{|c|}{ Produce } & \multicolumn{2}{|c|}{ Publish } & \multicolumn{2}{|c|}{ Present } \\
\hline & & $\mathrm{W} 2$ & W9 & $\mathrm{W} 2$ & W9 & W2 & W9 & W2 & W9 \\
\hline \multirow[t]{3}{*}{ Plan } & $\begin{array}{l}\text { Pearson Corre- } \\
\text { lation }\end{array}$ & 1 & 1 & .204 & $.572^{* *}$ & $.403^{*}$ & $.477^{* *}$ & -.053 & $.598^{* *}$ \\
\hline & Sig. (2-tailed) & & & .002 & .000 & .121 & .002 & .313 & .000 \\
\hline & $\mathrm{N}$ & \multicolumn{2}{|c|}{40} & \multicolumn{2}{|c|}{40} & \multicolumn{2}{|c|}{40} & \multicolumn{2}{|c|}{40} \\
\hline
\end{tabular}

**. Correlation is significant at the 0.01 level (2-tailed).

*. Correlation is significant at the 0.05 level (2-tailed).

There was a qualitative difference in how students approached their reading tasks. When working collaboratively, they established the reading focus more quickly and confidently than when working individually because they discussed the reading structure and determined the structural foundation at the beginning of the reading process and later for the e-story mapping process. E-story mapping in this module was seen both as a visual analysis tool and a visual knowledge management tool that enabled students to brainstorm, arrange, organize, and memorize the materials taught in class and reconstruct them again in a highly organized presentation using their own styles. After having decided what perspective they would like employ for their maps, students organized their individual or group e-story map contents with 
keywords, which was a preparatory step for quality writing.

4.2.2. Research Question 2. The second research question sought to explore the action of academic writing (plan, produce, publish, and present) with the use of $4 \mathrm{P}$ model. As seen in Table 1, the first two significant correlations are that of plan and present (0.598) and plan and produce (0.572). These show again that through the negotiation or revision of the e-story mapping, students addressed specific concerns in presentation and production. Though students' performance on publishing maps increased only slightly, from 0.403 to 0.477 , the increase still indicated a significant effect for the "plan-publish" learning pattern. "Publish" was a less difficult task for students in general, which allowed them the luxury to engage in writing, task discussions, and off-task discussions. In other words, a significant benefit of the online publication (LMS e-story map assignment zone) was that it encouraged a structured approach to the estory mapping. Online publication allowed students to focus on reading details and mat- ters of editing and responding. Thus, through the collaborative dialogue fostered by LMS, students constructed knowledge and created a specific "community of practice" (Swain, 2000; Wells, 2000)

With regard to Table 3, though the LMS publication has relatively smaller significance than production and presentation, it still has correlations with "produce" $(0.454)$ and "present" (0.361). Although students admitted that they adopted a different manner according to their preference for work individually or collaboratively, their perceptions of LMS publication exhibited some common trends. When working on an online publication, students became aware that every single map uploaded to the LMS was unique and that they could learn more from reading others' maps. In addition, students' structure and organization skills improved because the discussion allowed students to think in a more focused and organized manner. Although the students disagreed sometimes, overall they liked working with others due to the planning assistance that their community members could offer.

Table 3. Correlations of 4P Performance (Weeks $2 \&$ 9, 4P Model).

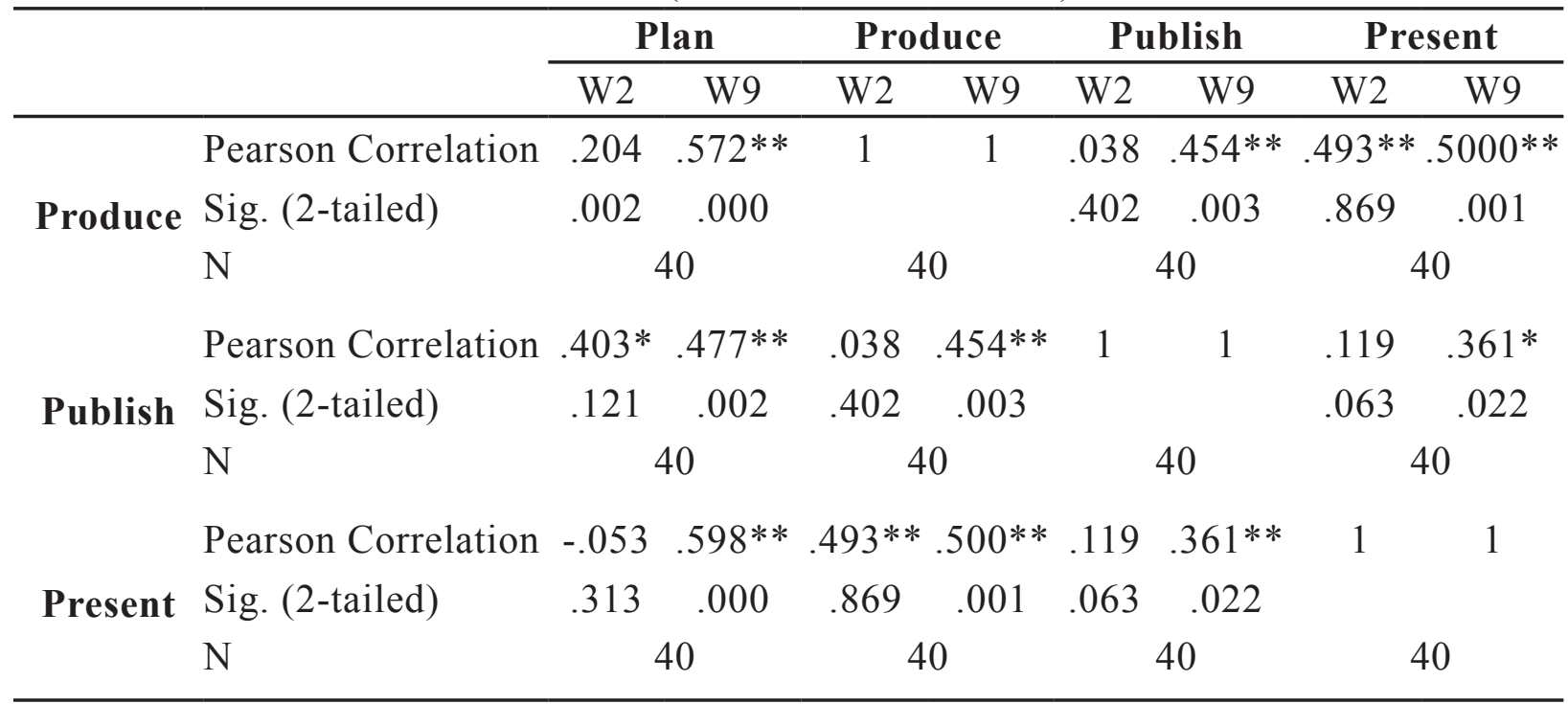

** Correlation is significant at the 0.01 level (2 tailed).

* Correlation is significant at the 0.05 level ( 2 tailed). 
When working individually, students preferred to revise their maps toward the end of the writing process when the maps were almost completed. But when working collaboratively, they tended to edit their map during the process of organizing the drafts. The difference in the revising pattern could be due to the fact that in the collaborative e-story mapping, the students had readers to whom they could talk and with whom they could negotiate. This finding also implied that the more the students planned, the better their e-story maps would be. But, the different ways of working (individual and collaborative) did not influence the correlations between planproduce, plan-publish, and plan-present. This indirectly answers the third research question, "Was the 4P model more effective when students got more involved in their e-story mapping?"
4.2.3. Research Question 3. The data comprised observational records and artifacts from the university LMS during the semester (weeks $2,4,6,7,9,13$, and 17). In response to research question three, the results of the present research show that the more the participants were exposed to the 4P model and became involved in the e-story mapping, the more they would organize their e-story maps and better improve their critical reading and writing skills (see Figure 4). The graph shows that students struggled less with how to plan, produce, and publish than how to present, which is a general problem for English education in Taiwan. So, when students go to a university, this problem also influences their academic performance.

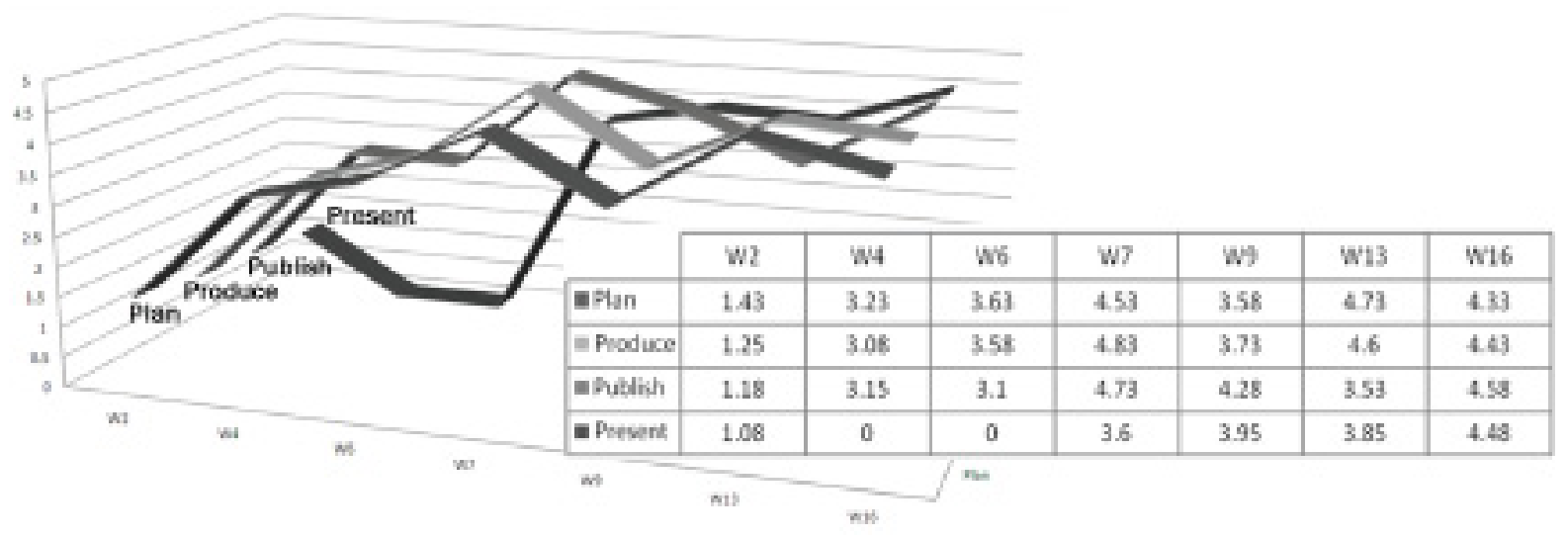

Figure 4. 4P Performance Progress (Weeks 2, 4, 6, 7, 9, 13, and 17, 4P Model).

However, students' average critical reading and writing skills in applying the 4Ps increased from as low as 1.4250 (plan, $S D=.47434)$ to 4.3250 (plan, $S D=.50064) ; 1.2500$ (produce, $S D=.43853)$ to 4.4250 (produce, $S D=.54948)$; 1.1750 (publish, $S D=.38481$ ) to 4.5750 (publish, $S D=.50064$ ); and 1.0750 (present, $S D=$ .26675 ) to 4.4750 (present, $S D=.50574$ ). This means that students can overcome the presentation problem if they know how to deal with obstacles to their performance. That is, the more students read and write with the $4 \mathrm{P}$ model, the more they apply their critical thinking to e-sto- ry mapping (see Tables $4,5,6$, and 7) and the better their coursework.

4.2.4. Research Question 4. The results presented above for questions 1,2 , and 3 also show that effective critical communication in reading depends on procedural skills that develop only through use, and students who enjoy a high degree of social autonomy in their learning environment should find it easier than to master the full range of discourse roles on which effective spontaneous communication depends. Stevick (1980) asserted that enhancing this process of self-fulfillment, 
Table 4. Plan Progress (Weeks 2, 4, 6, 7, 9, 13, and 17, 4P Model)

\begin{tabular}{rrrrrrrrr}
\hline & w2 plan & w4 plan & w6 plan & w7 plan & w9 plan & w13 plan & w16 plan \\
\hline $\mathrm{N}$ & Valid & 40 & 40 & 40 & 40 & 40 & 40 & 40 \\
& Missing & 0 & 0 & 0 & 0 & 0 & 0 & 0 \\
Mean & 1.4250 & 3.2250 & 3.6250 & 4.5250 & 3.5750 & 3.7750 & 4.3250 \\
& $S D$ & .50064 & .69752 & .62788 & .50574 & .54948 & 1.42302 & .47434 \\
& .251 & .487 & .394 & .256 & .302 & 2.025 & .225 \\
\hline
\end{tabular}

Table 5. Produce Progress (Weeks 2, 4, 6, 7, 9, 13, and 17, 4P Model)

\begin{tabular}{|c|c|c|c|c|c|c|c|c|}
\hline & & $\begin{array}{r}\mathrm{w} 2 \\
\text { produce }\end{array}$ & $\begin{array}{r}\mathrm{w} 4 \\
\text { produce }\end{array}$ & $\begin{array}{r}\text { w6 } \\
\text { produce }\end{array}$ & $\begin{array}{r}\mathrm{w} 7 \\
\text { produce }\end{array}$ & $\begin{array}{r}\text { w9 } \\
\text { produce }\end{array}$ & $\begin{array}{r}\text { w13 } \\
\text { produce }\end{array}$ & $\begin{array}{r}\mathrm{w} 16 \\
\text { produce }\end{array}$ \\
\hline \multirow[t]{5}{*}{$\mathrm{N}$} & Valid & 40 & 40 & 40 & 40 & 40 & 40 & 40 \\
\hline & Missing & 0 & 0 & 0 & 0 & 0 & 0 & 0 \\
\hline & Mean & 1.2500 & 3.0750 & 3.5750 & 4.8250 & 3.7250 & 3.9750 & 4.4250 \\
\hline & $S D$ & .43853 & .76418 & .59431 & .38481 & .67889 & 1.44093 & .54948 \\
\hline & Variance & .192 & .584 & .353 & .148 & .461 & 2.076 & .302 \\
\hline
\end{tabular}

Table 6. Publish Progress (Weeks 2, 4, 6, 7, 9, 13, and 17, 4P Model)

\begin{tabular}{|c|c|c|c|c|c|c|c|c|}
\hline & & $\begin{array}{r}\text { w2 } \\
\text { publish }\end{array}$ & $\begin{array}{r}\text { w4 } \\
\text { publish } \\
\end{array}$ & $\begin{array}{r}\text { w6 } \\
\text { publish } \\
\end{array}$ & $\begin{array}{r}\text { w7 } \\
\text { publish } \\
\end{array}$ & $\begin{array}{r}\text { w9 } \\
\text { publish }\end{array}$ & $\begin{array}{r}\text { w13 } \\
\text { publish } \\
\end{array}$ & $\begin{array}{r}\text { w16 } \\
\text { publish }\end{array}$ \\
\hline \multirow[t]{5}{*}{$\mathrm{N}$} & Valid & 40 & 40 & 40 & 40 & 40 & 40 & 40 \\
\hline & Missing & 0 & 0 & 0 & 0 & 0 & 0 & 0 \\
\hline & Mean & 1.1750 & 3.1500 & 3.1000 & 4.7250 & 4.2750 & 4.1000 & 4.5750 \\
\hline & $S D$ & .38481 & .86380 & .87119 & .45220 & .75064 & 1.48151 & .50064 \\
\hline & Variance & .148 & .746 & .759 & .204 & .563 & 2.195 & .251 \\
\hline
\end{tabular}

Table 7. Present Progress (Weeks 2, 4, 6, 7, 9, 13, and 17, 4P Model)

\begin{tabular}{rrrrrrrrr}
\hline & \multicolumn{2}{c}{$\begin{array}{c}\text { w2 } \\
\text { present }\end{array}$} & \multicolumn{1}{c}{$\begin{array}{c}\text { present } \\
\text { present }\end{array}$} & $\begin{array}{c}\text { w7 } \\
\text { present }\end{array}$ & $\begin{array}{c}\text { w9 } \\
\text { present }\end{array}$ & $\begin{array}{c}\text { w13 } \\
\text { present }\end{array}$ & $\begin{array}{c}\text { w16 } \\
\text { present }\end{array}$ \\
\hline $\mathrm{N}$ & Valid & 40 & 40 & 40 & 40 & 40 & 40 & 40 \\
& Missing & 0 & 0 & 0 & 0 & 0 & 0 & 0 \\
& Mean & 1.0750 & .0250 & .0000 & 3.6000 & 3.9500 & 3.8500 & 4.4750 \\
& $S D$ & .26675 & .15811 & .00000 & .49614 & .71432 & 1.38767 & .50574 \\
& Variance & .071 & .025 & .000 & .246 & .510 & 1.926 & .256 \\
\hline
\end{tabular}


therefore facilitating learning, is a critical task for the teacher. That is, if students are reflectively engaged with their e-story maps, the e-maps are more likely to be efficient and effective because they are more personal and focused; in particular, what is learned in educational contexts with the $4 \mathrm{P}$ model is more likely to help students' reading and writing agendas. In addition, if students are practically committed to their e-story maps, the problem of critical reading and writing can be solved strategically; although they may not always feel entirely positive about all aspects of their e-story maps, students develop the reflective and attitudinal resources necessary to overcome temporary motivational setbacks.

The Project helped students write and read critically under a framework of reading and writing and at the same time mapping it out. The e-story maps the students constructed were not a one-way, but a multi-way communication. By publishing the maps on the LMS, the students had the possibility of writing for the readers other than classmates. In the process, students find it easier to read and write academically with e-story maps and able to recognize and give advice about clear and effective academic reading and writing skills in the maps they posted. The potential value of interacting with a dramatic text was increased when students were engaged in e-story mapping to express their ideas.

\subsection{Research Limitation and Suggestion}

The data comprised observational records and artifacts of the Project during the semester. Though the results of the investigations help the researcher generate future inquiries and possible research directions, a practical evaluation from the students' perspective is needed, and one founded on a sound theoretical basis. The integration of LMS networks into teaching for academic purposes depends on two major factors for its successful implementation - vari- ous creative uses of the technology and directed-driven approaches.

There are several limitations in this study that need to be addressed. First, the low number of learner participants (though $\mathrm{N}=40$ is the maximum size of a class) means that the study cannot provide generalizable conclusions. Because of the low number of learnerparticipants, statistically significant differences were very high. Second, this study focused exclusively on e-story mapping. Obviously, the type of graphic organizer used will need to vary according to its cognitive demands. Finally, more general research must be conducted in the area of collaborative reading and writing processes for academic purposes based on theoretical models. Little published material is available particularly in relation to e-story mapping of human-human communication mediated by and independent from computers in a Taiwanese context.

\section{Conclusion}

The sequence in which students completed the e-story map tasks may have affected the results of this study. Finalizing the e-story maps for each literary text, students learned how to engage in academic reading and writing, and the more they became involved in making their e-story maps, the faster they could handle the 4P model for knowledge management. Traditionally, general education does not enable students to develop strong critical reading and writing skills. The current study endeavored to rectify that by coming up with and testing a learning strategy. This class differs from common general education classes for non-English majors in three ways. First, the class focused on students' development of the ability to think aloud for academic purposes. Second, the class invited students to incorporate some elements of online publishing (LMS discussion zone and assignment zone) into the class. Third, a series 
of core exercises in topic collages ran through the semester like a backbone culminating in the finalized and organized map publications. Also, it focused on the possible challenges that academic reading and writing may pose to students as they tried to meet the requirements of the discourse communities in class.

The researcher found that students at many different levels benefit from the extra e-story mapping done in discussions and from its use to practice communicating meaningfully in real contexts. Emphasizing the reading and writing processes, genre awareness, and learning partnerships as viable and stimulating methods also helped students improve their academic interpersonal and communication skills. By publishing the maps on the LMS, students gained the chance to produce academic writing for classmates as well as academic readers, and at the same time, their sharing and accumulation of knowledge were all built on the basis of knowledge management. Students integrated knowledge to resolve the problems of literary knowledge drained by placing information in e-story maps. The increasing e-story map production and decreasing redundancy in print shows students' best use of collaborative knowledge. The success of this Project relied on a clear understanding of the benefits it brought to students, as well as on the recognition of the factors that enhance efficient and effective use.

\section{References}

Allen, M. W. (2003). Michael Allen's guide to e-learning: Building interactive, fun and effective learning programs for any company. Hoboken, NJ: John Wiley \& Sons.

Baumann, J. F., \& Bergeron, B. S. (1993). Story map instruction using children's literature: Effects on first graders' comprehension of central narrative elements. Journal of Literacy Research, 25(4), 407-437.
Bellanca, J. (1990). The cooperative think tank: Graphic organizers to teach thinking in the cooperative classroom. Arlington Heights, IL: IRI/SkyLight.

Berkeley, S., Scruggs, T. E., \& Mastropieri. M. A. (2010). Reading comprehension instruction for students with learning disabilities, 1995-2006: A meta-analysis. Remedial and Special Education, 31(6), 423-436.

Daniel, J., \& Marquis, C. (1988). Interaction and independence: Getting the mix right. In D. Sewart, D. Keegan, \& B. Holmberg (Eds.), Distance education: International perspectives (pp. 339-359). New York: Routledge.

Davis, Z. T., \& McPherson, M. D. (1989). Story map instruction: A road map for reading comprehension. The Reading Teacher, 43(3), 232-240.

Duke, N. K., \& Pearson, P. (2002). Effective practices for developing reading comprehension. In A. E. Farstrup \& S. Samuels (Eds.), What research has to say about reading instruction (pp. 205-242). Newark, DE: International Reading Association.

Dunlosky, J., \& Metcalfe, J. (2009). Metacognition. Los Angeles: Sage.

Edmonds, M. S., Vaughn, S., Wexler, J., Reutebuch, C., Cable, A., Tackett, K. K., \& Schnakenberg, J. W. (2009). A synthesis of reading interventions and effects on reading comprehension outcomes for older struggling readers. Review of Educational Research, 79 (1), 262-300.

Francescato, D., Porcelli, R., Mebance, M., Cuddetta, M., Klobas, J., \& Renzi, P. (2006). Evaluation of the efficacy of collaborative learning in face-to-face and computer-supported university contexts. Computer in Human Behavior, 22, 163-176.

Idolis, L. (1987). Group story mapping: A comprehension strategy for both skilled and unskilled readers. Journal of Learn Disabilities, 20, 196-205.

Jonassen, D. H. (1996). Computers in the 
classroom: Mindtools for critical thinking. Englewood Cliffs, NJ: Prentice-Hall.

Katayama, A. D., \& Robinson, D. H. (2000). Getting students "partially" involved in note-taking using graphic organizers. Journal of Experimental Education, 68, 119134.

Kolb, D. A. (1984). Experiential learning: Experience as the source of learning and development. Englewood Cliffs, NJ: PrenticeHall.

Markwood, R., \& Johnstone, S. (1994). New pathways to a degree: Technology opens the college. Boulder: Western Interstate Commission for Higher Education.

Moore, M. (1989). Editorial: Three types of interaction. The American Journal of Distance Education, 3(2), 1-7.

Pearson, P. D. (1985). Changing the face of reading comprehension instruction. The Reading Teacher, 38(8), 724-738.

Resta, P., \& Laferriere, T. (2007). Technology in support of collaborative learning. Educational Psychology Review, 19, 65-83.

Spivey, N. N. (1989). Construing constructivism: Reading research in the United States. Occasional paper No. 12. Retrieved from ERIC database. (ED310358).

Stahl, G., Koschmann, T., \& Suthers, D. (2006). Computer-supported collaborative learning: An historical perspective. In R. K. Swayer (Ed.), Cambridge handbook of the learning sciences (pp. 409-426). Cambridge, UK: Cambridge University Press.

Stahl, K. A. D. (2004). Proof, practice, and promise: Comprehension strategy instruction in the primary grades. The Reading Teacher, 57(7), 598-609.

Stein, N., \& Glenn, C. (1979). An analysis of story comprehension in elementary school children. In R. D. Freedle (Ed.), Advances in discourse processes: Vol. 2. New directions in discourse processing (pp. 53-119). Norwood, NJ: Albex.

Stevick, E. W. (1980). Teaching languages:
$A$ way and ways. Rowley, MA: Newbury House.

Storch, N. (2005). Collaborative writing: Product, process, and students' reflections. Journal of Second Language Writing, 14(3), 153-173.

Swain, M. (2000). The output hypothesis and beyond. In J. Lantolf (Ed.), Sociocultural theory and second language acquisition (pp. 97-114). Oxford: Oxford University Press.

Tarquin, P., \& Walker, S. (1997). Creating success in the classroom: Visual organizers and how to use them. Englewood, CO: Teacher Ideas Press.

Thornburg, D. D. (1998). Brainstorms and lightning bolts: Thinking skills for the 21 $1^{\text {st }}$ century. San Carlos, CA: Starsong.

Wells, G. (2000). Dialogic inquiry in education. Building on the legacy of Vygotsky. In C. Lee \& P. Smagorinsky (Eds.), Vygotskian perspectives on literacy research. Constructing meaning through collaborative inquiry (pp. 51-85). Cambridge, UK: Cambridge University Press.

Westera, W. (2010). Technology-enhanced learning: Review and prospects. Serdica Journal of Computing, 4, 159-182.

Zipprich, M. A. (1995). Teaching web making as a guided planning tool to improve student narrative writing. Remedial and Special Education, 16, 3-15.

\section{Contact the Author}

Ai Chun Yen, Ph.D

Dong Hwa University, Taiwan

E-mail: acyen@mail.ndhu.edu.tw 